\title{
INCORPORATING POVERTY IN SOCIETY INTO STRATEGIC HUMAN \\ RESOURCE MANAGEMENT
}

\begin{abstract}
In developed societies, the cultural value of social trust and cooperative behavior decreases when levels of poverty increase. Based on the contextual social exchange perspective, we argue that these societal traits can be transmitted to companies located within such societies, resulting in a reduction of human resource (HR) investment and a decrease in the effect of these HR investments on workforce performance. Therefore, poverty in society has a dual role in its connection with HR investment, acting both as an antecedent and as a moderator. The employment relationship is dependent on the deprivation and poor quality of life of people in the region. We arrive at this conclusion from a study conducted on a sample of 2,192 companies during a period of six years and applying longitudinal structural equation modeling. Findings indicate the importance of placing HR practices within their socioeconomic environment, specifically living conditions, to understand their implementation and return over time.
\end{abstract}

Keywords: AROPE index, HR investment, longitudinal analysis, organizational performance, society-organization link. 


\section{INTRODUCTION}

The problem of poverty in society is not limited to developing countries (Anand and Sen, 1997, Atkinson, 1998, Gábos et al., 2015, Wagle, 2008). Indeed, one of the effects of the economic crisis triggered in 2008 is the remarkable rise in poverty in many developed countries. This increase is the consequence of economic decline and the unequal distribution of wealth in developed societies (Bourguignon, 2004; Iceland, 2003). The concept of poverty refers to scarcity of resources and poor quality of life. Poverty is manifested as the denial of the most fundamental opportunities and options for human development and denotes a lack of economic means to fulfill basic human needs (Anand and Sen, 1997; Atkinson, 1998; Bapuji, 2015; Wagle, 2008). The economic crisis has not only led to increased levels of poverty, but has also widened regional differences in several countries, particularly in Europe, where the new socioeconomic environment is characterized by greater and more disparate levels of poverty among the regions (Copus et al., 2015; Piacentini, 2014; Węziak-Białowolska, 2015). As a result, reducing poverty is now a key policy component of the Europe 2020 strategy to achieve the inclusive growth of the European economy, improving both the welfare of society and firms' competitiveness (European Commission, 2010).

The importance of linking the environment and its social, economic and political factors with organizations' human resource management (HRM) systems is a recognized central theme in the strategic HRM literature (e.g., Jackson et al., 2014, Kaufman, 2012). This field of research encompasses the HR practices and investments of an organization, as well as its relations with other internal and external elements, to evaluate their effect on organizational performance. In the contemporary European context, it seems pertinent and innovative to examine whether levels of poverty in society affect HR investments and their impact on firm performance. Social phenomena, especially poor socioeconomic conditions, 
should be given more attention in organizational research (Diehl et al., 2018) and although scholars in other disciplines have considered poverty as an important topic-for example, the "bottom of the pyramid" literature (Kolk et al., 2014) — this subject has attracted very little research within the field of strategic HRM. Likewise, empirical studies have generally ignored the embedded and contextualized nature of HR investments (Coyle-Shapiro and Shore, 2007; Jackson et al., 2014; Lewis et al., 2018; Vincent et al., 2018).

The aim of the present study is to bridge this gap by introducing poverty in society into the realm of strategic HRM. To the best of our knowledge, this is the first study that examines the connection between poverty in society, HR investment, and firm performance. To recognize the impact of poverty in society on organizations, we adopt the contextual employment relationship theory (Coyle-Shapiro and Shore, 2007; Coyle-Shapiro et al., 2004; Schalk, 2004). This theory holds that societal traits shape the context for the social exchange between employers and employees, so the cultural norms and values of society related to social exchanges (e.g., trust and cooperation) have an impact on the employment relationship of the organizations located within that society. Following this theoretical approach, we advocate that poverty is a contextual factor that affects the level of HR investment (antecedent) and also modifies the impact of $\mathrm{HR}$ investment on labor productivity (moderator). This possible dual role of a contextual variable is highlighted by Johns (2017, p. 587), who suggests that "context effects can comprise both main effects and interactions between context variables and substantive variables of interest".

To empirically examine the above effects, we designed a moderated mediation model for panel data, based on longitudinal structural equation modeling methodology. As Jackson et al. (2014) note, the dynamic nature of strategic HRM is a prominent feature of empirical research in this field. Investments in human resources cannot be understood without examining their interrelationship with the environment, and this interdependence is inherently 
dynamic. Likewise, the contextual employment relationship framework has identified the need for longitudinal studies to capture the dynamic interaction over time between societal factors and the employment relationship (e.g., Schalk, 2004). Paradoxically, despite these considerations the use of longitudinal analysis in strategic HRM is still scarce because they are resource intensive (time and money) and complex (Saridakis et al., 2017).

\section{Insert figure 1 about here}

\section{THEORETICAL FRAMEWORK}

\section{Poverty in society}

The concept of poverty has a long tradition in most societies and cultures, each of which understands it differently since it is defined according to the socioeconomic context of each society in a given period. Because of these variations, a single, universally valid concept cannot easily be derived, although a common denominator across this variety of meanings is that poverty always refers to certain deprivations that jeopardize people's well-being (Anand and Sen, 1997; Atkinson, 1998). In this vein, one way to define poverty is by establishing the limits of deprivation that each society considers inacceptable. The United Nations Development Program (UNDP, 1997; p. 15) specifies these characteristics by defining the concept of poverty in contrast to the concept of human development: "If human development is about enlarging choices, poverty means that opportunities and choices most basic to human development are denied - to lead a long, healthy, creative life and to enjoy a decent standard of living, freedom, dignity, self-respect and the respect of others". The contrast between the concepts of development and poverty reflects two different ways of assessing the welfare of a society. The first concerns the progress of all groups in the society; the second judges well- 
being according to the progress made to reduce the disadvantages of people deprived of resources.

Poverty in society is therefore a complex, multifaceted phenomenon, and as a result, it can be conceptualized from a range of approaches and measured by multiple indicators. Wagle (2008) identifies three main approaches to conceptualize poverty: economic wellbeing, capability, and social inclusion. The concept of economic well-being links poverty with economic deprivation, and is related to material aspects of monetary income and consumption that provide a decent minimum standard of living. The capability approach understands poverty as a state of deprivation of capability or functioning that occurs when people do not have the freedom, health, or education to acquire or expand their capabilities. The third approach, based on social exclusion, refers to a process of systematic isolation, rejection, lack of social support, and denial of participation. Employment is understood to be one of the key elements in the organization of an individual's personal and social relationships. Poverty is frequently defined and operationalized by integrating several of these approaches, thus building a composite multidimensional construct. Illustrative examples of multidimensional poverty indices, endorsed by international organizations, are the human poverty index (HPI) and the "at risk of poverty or social exclusion" (AROPE) index.

The UNDP developed the HPI to assess the degree of poverty in society based not only on insufficient monetary income but also on a series of other non-monetary factors (Anand and Sen, 1997). Since 1997, the UNDP has distinguished between the living conditions in the developing countries and those in the developed countries of the Organization for Economic Co-operation and Development (OECD), and constructs a different HPI for each of these two contexts. In both socioeconomic environments, the HPI contains the same three components to define human poverty (health, education and material well-being). However, more demanding levels are used to determine poverty in developed 
countries, and social exclusion (long-term unemployment) has been added as a new criterion of human deprivation. Since 2010 the UNDP has introduced a new multidimensional poverty index to measure extreme poverty, applicable only to developing countries, and no longer produces the HPI for developed countries.

Currently in Europe the most widely used and best known measure is the AROPE index, as it is the main statistic of the European Commission to monitor progress towards the target of the Europe 2020 strategy to reduce poverty in European Union (EU) member states (European Commission 2010; Gábos et al., 2015; Węziak-Białowolska, 2015). The AROPE index is based on the Living Conditions Survey (LCS) that has been carried out since 2004 following harmonized criteria for all EU countries. The LCS provides the European Commission with an excellent statistical instrument for analyzing poverty. The data for the AROPE index are gathered by the authorities in each member state and submitted to the statistical office of the EU (Eurostat) for analysis; based on this analysis Eurostat produces comparable and harmonized results of community policies (Eurostat, 2018). In Spain, the National Institute of Statistics (Instituto Nacional de Estadística, INE) is responsible for constructing the AROPE index and obtaining the primary data (i.e., the LCS).

According to the INE, the household is the unit of analysis for the AROPE index, and it defines people in any one of the following three situations as living in poverty: 1) people who live in households with an income lower than $60 \%$ of the median national income; 2) people in states of severe material deprivation, defined as those who live in households where members are unable to afford at least four of the following nine items: their rent, utility bills, hire purchase installments or other loan payments; adequate heating for their home; unexpected expenses; meat, fish or other protein-rich nutrition every second day; a week-long holiday away from home; a car; a washing machine; a color TV; or a telephone; 3) people living in a household with low work intensity (less than $20 \%$ of all household members' total 
potential to work). The AROPE index therefore combines economic (household's level of income and consumption possibilities) with social (joblessness) issues (Eurostat, 2018). Persons who fall into two or three of these situations are only counted once. Finally, the AROPE index is expressed as the percentage of the total population represented by these people. This ratio of poverty is provided yearly for each EU state and region.

\section{Poverty and social trust}

Poverty in society is negatively related to social trust. Social trust, or generalized interpersonal trust, is a moral value that derives from shared cultural norms in a community that believes in the goodwill of others, and describes a context where people tend to be generous and even altruistic (Uslaner, 2002). Social trust is an ethical mandate to treat people as if they were trustworthy. Trustworthiness is reflected in characteristics such as honesty, fairness, and loyalty. Social trust brings benefits for societies as a medium of social cooperation that allows individual and collective capabilities (e.g., knowledge and creativity) to expand, and provides existential security and certainty by building upon people's goodwill (Warren, 2018). It is not easy to conceive a welfare society without generalized trust relationships, the cornerstone of cooperative behavior.

Poverty and inequality ${ }^{1}$ are allied with the growth of the shadow economy and corruption, which leads to a degradation of society by reducing citizens' welfare and social trust (Bapuji, 2015; Čiutienė et al., 2015; Diehl et al., 2018; Rothstein and Uslaner, 2005; You, 2018). The shadow economy, expressed in the growth of illegal labor and unaccounted income, increases social differentiation and distrust in the state (Čiutienė et al., 2015). Illegal labor escalates rates of mistreatment due to improper working conditions, which increases the

\footnotetext{
${ }^{1}$ Inequality plays a larger role in explaining trends in poverty because in societies with high levels of unequal distribution of wealth, low-income families often suffer material deprivation (Iceland, 2003).
} 
social separation of the people affected by them. Reduced annual tax revenue weakens a government's social policy and the poor become poorer to the advantage of the rich. In highly stratified societies, people are more insulated and individuals from different social strata are less likely to meet each other, resulting in less trust, less social deference and weakened social cohesion (Bapuji, 2015; Steijn and Lancee, 2011; Uslaner, 2002). Corruption aggravates mistrust because dishonest governments transfer resources from the general public to the elites (generally, from the poor to the rich) and reward only those that show their obedience (i.e., political clientelism) rather than larger society, by reducing public welfare policies to meet social needs (Rothstein and Uslaner, 2005). Levels of social trust in countries or regions are negatively affected by corruption (You, 2018).

Additionally, studies examining the relationship between the availability of resources and social trust find that these two factors are closely related, so that where resources are scarce, mistrust develops (e.g., Delhey and Newton, 2005; Haushofer, 2013; Haushofer and Fehr, 2014; Steijn and Lancee, 2011). Material deprivation can affect social-emotional health, and individuals living in poverty show fewer prosocial attitudes, lower trust, more feelings of loneliness, lower risk-taking behavior, and more short-sightedness than richer people (Haushofer, 2013). Scarcity makes people apprehensive and reduces their trust in each other. The wealthier the society, and the more it meets basic material needs, the more its members are able to take risks by virtue of their trusting attitudes, while, at the same time, making it both less necessary and less rewarding to act in an untrustworthy manner (Delhey and Newton, 2005). In other words, people in richer countries or regions face fewer risks and are therefore more likely to trust others.

\section{Social exchange theory: a contextual view}

Social exchange theory adheres to the rules of mutual commitment between employees and the organization and is established on the cultural values of trust and fairness 
that support cooperative behavior, in such a way that the granting of a benefit creates the obligation to reciprocate (Coyle-Shapiro and Shore, 2007; Coyle-Shapiro et al., 2004). Trust and loyalty are required between the parties in the social exchange because there is some inherent risk that the benefits provided will not be returned since the nature and timing of these benefits are not specified (Cropanzano and Mitchell, 2005). The employment relationship is a social exchange between inducements offered by employers and contributions returned by employees (Wang et al., 2003). To borrow Uslaner's (2002) term, the employment relationship is built on "strategic trust" because it is a deal between specific people (i.e., employers and employees) for a particular setting (i.e., organization) with the objective of reducing the risk inherent in the play of reciprocity.

Social exchange theory can be examined both at an individual and organizational level (Wang et al., 2003). We adopt the organizational level based on the inducement-contribution model (March and Simon, 1958; Tsui et al., 1997), which defines the employment relationship from the employer's perspective and views the social exchange relationship or reciprocity as the positive effect of $\mathrm{HR}$ investment ${ }^{2}$ (i.e., inducement) on workforce performance (i.e., contribution). The empirical evidence supporting this theory is abundant (e.g., Allen et al., 2013; Shaw et al., 2009; Subramony et al., 2008; Sun et al., 2007). Firms

\footnotetext{
${ }^{2}$ When the strategic HRM literature deals with social exchange theory, different terms are used to reflect the inducement side of an employment relationship. For example, Shaw et al. (1998) use the term "investment-focused HRM strategy", Shaw et al., (2009) call it "HRM inducements and investments" and, more recently, Roh and Kim (2016) seem to favor the expression "HRM investments". Batt (2002), drawing on the study by Shaw et al., (1998), prefers the term "human resource incentives". More recently, Roca-Puig et al., (2018), based on these previous works, use the term "HR investment". Since we apply the measure conceived by Roca-Puig et al., (2018) in our empirical section, we believe it is more consistent to respect and maintain their designation.
} 
provide superior HR investment and employees reciprocate with superior organizational commitment and efficient work that benefit the organization. HR practices such as training, competitive remuneration, and job security indicate organizational commitment to employees (OCE) (Lee and Miller, 1999) and can be considered as HR investment offered by the firm to its employees (Batt, 2002; Roca-Puig et al., 2018, Shaw et al., 1998, 2009). The employee's response to these incentives can be revealed in the form of favorable employee attitudes (Tsui et al., 1997) and citizenship behaviors (Sun et al., 2007), lower dismissal, quit and turnover rates (March and Simon, 1958; Shaw et al., 1998, 2009; Sun et al., 2007), and increased operational performance, usually in the form of productivity improvements (Subramony et al., 2008; Sun et al., 2007). Labor productivity is one of the main criteria to evaluate the employee contribution to the organization (March and Simon, 1958).

The employee-organization relationship is dependent upon the sociocultural context in which social exchanges are embedded (Cropanzano and Mitchell, 2005; Coyle-Shapiro and Shore, 2007; Coyle-Shapiro et al., 2004; Hannah and Iverson, 2004; Kim and Wright 2011; Schalk, 2004). According to these authors, environmental changes affect the employeeorganization relationship, making it necessary to incorporate the contingent nature of social exchange. The employment relationship is conditioned by the prevailing moral considerations and social behavior in the society in which a firm develops its productive activity. This contextual view of the employment relationship holds that a society's cultural values in relation to social exchanges are permeable and are imported into the organization, thus involving reciprocity and affecting the inducements provided by employers as well as the probability that these inducements will be reciprocated by employees. Therefore, variances in regional cultures provide an influential context for social exchange by constraining or reinforcing organizational behavior to act in a mutually committed way (Coyle-Shapiro et al., 2004; Kim and Wright 2011). Given the divergent degree of poverty in different regions 
(Copus et al., 2015, Piacentini, 2014) and, consequently, the different degree of social trust and cooperative behavior (Čiutienè et al., 2015; Diehl et al., 2018; Haushofer and Fehr, 2014), Coyle-Shapiro et al.'s (2004) and Kim and Wright's (2011) claim is particularly relevant for our study.

In this regard, Kim and Wright (2011) suggest that social exchange relations between employer and employees could be affected by societal level of trust, and thereby affect the effectiveness of HR investments. When there is low trust in a society, employees are less inclined to trust their employer, and managerial practices, such as HR investments, are less likely to be interpreted as an employer's genuine commitment to employees. Unless employees perceive HR investment as an actual incentive, it may not effectively lead to a positive social exchange relationship between employees and employers and, therefore, HR investment will not benefit the firm (Kim and Wright, 2011). For example, if employees perceive that the management's commitment to job security cannot be trusted, they may not have favorable attitudes nor make greater efforts in their work because they fear that enhanced productivity might lead to the reduction of the workforce. By contrast, in a societal context characterized by high levels of social trust, employees tend to trust employers, which facilitates the successful implementation of HR investment. Social trust enables firms to easily generate positive social exchange relations with their employees through $\mathrm{HR}$ investments. In summary, the relationship between HR investments and employees' response in terms of workforce performance will be greater in higher social trust contexts than in lower social trust contexts (Kim and Wright, 2011).

The contextual view of the employment relationship embraces Johns' (2017) proposition that the attitudes and behaviors of people in organizations derive from factors in the business environment. Authors such as Bapuji (2015), Leana et al. (2012) and Pitesa et al. (2017) have also proposed that organizational behavior cannot be detached from the 
surrounding social situation, and consequently, when individuals experience inequality and poverty in their society, the impact spreads to all the other social groups they belong to, particularly the organization in which they work. In particular, poverty in society produces distrustful employees and organizational behaviors of indifference and lack of participation at work. Employees with both high (rich) and low (poor) economic status can show indifference at work, although in different ways (Bapuji, 2015). Employees with high economic status tend to put their own interests above the well-being of other workers and the organization in general. Employees with low economic status tend to hinder the construction of a long-term strategic commitment with the organization. They may lack employment aspirations and, therefore, they may make less effort and become more apathetic. Less collaborative and more passive employee behaviors can weaken their level of response to the incentives the organization offers to increase their organizational commitment; the operational consequence of this situation is that the effect of HR investment on labor productivity will be weakened.

Adopting the contextual vision of social exchange theory, Las Heras et al. (2015) and Bosch et al. (2018) argue that employees regulate their efforts, dedication and intention to reciprocate towards the organization not only in exchange for tangible assets such as their salary, but they are also conditioned by the cultural values of the society in which they have formed their social network. These authors examine how the effect of family supportive supervisor behavior (FSSB), a possible HR investment within an OCE system, on employees' outcomes is moderated by different features of national contexts related to the level of welfare in a society. In particular, Las Heras et al. (2015) found that FSSB has a greater positive impact on job performance in supportive national contexts (i.e., high social expenditure and low unemployment rate) than in unsupportive contexts. Bosch et al. (2018) examine gender inequality as a potential moderator of the positive effect of FSSB on employee motivation at work, and found one negative interaction between gender inequality and FSSB, showing that 
this effect is stronger in countries with low rather than high gender inequality. Las Heras et al. (2015) and Bosch et al. (2018) conclude that in welfare contexts, employees are more likely to recognize and value HR investment, and will work harder when they receive the benefits of such investment. In these contexts, employees expect and value organizational support and, therefore, they will respond positively to the HR investment by employers, significantly increasing job performance. The opposite is true for impoverished environments, in which HR investment may be relatively unnoticed because employees receive signals from the environment that reciprocity is not so important. Consequently, we hypothesize that:

H1. Poverty in a society (region) will negatively moderate the relationship between HR investment and labor productivity of organizations within that region, such that the higher the poverty, the lower the positive effect of HR investment on labor productivity.

The belief system underlying regional cultures legitimizes the extension of HR investment and explains that cultural values in particular nations or regions influence the size of the inducement organizations provide (Coyle-Shapiro et al., 2004; Hannah and Iverson, 2004; Schalk, 2004). We observe that the contextual view of the employment relationship is founded on the institutionalization of HRM practices (Lewis et al., 2018; Suchman, 1995), which centers on cognitive legitimacy fostered by the environment. Legitimacy is a generalized perception or assumption that the actions of an entity (e.g., organization) are appropriate within a given socially constructed system of norms, values, and beliefs (Suchman, 1995). When HR investments gain high levels of cognitive legitimacy, they become taken for granted and unquestioned (Lewis et al., 2018). We propose that the prevailing cultural norms and social values in an impoverished developed society (i.e., lack of social trust) make a reduced level of HR investment seem appropriate, from the point of view of both employers and employees. 
Legislative reforms allowing employers to freeze salaries and encouraging the use of temporary contracts are associated with growing rates of poverty in developed societies. Recent reforms to employment legislation in European countries such as Spain, France and Italy, for example, allow firms to gradually introduce more flexible labor conditions, with the resulting increase in precarious employment and lower salaries. In addition, cuts in publicly funded grants and subsidies for employee training courses has also led to a fall in in-house training; firms are therefore less likely to invest in training, since it has been demonstrated that more training programs are run when firms have access to subsidies (Popov, 2014). According to Hannah and Iverson (2004), although in theory employers would have more freedom if there were no labor regulation, in practice the lack of public supervision and financial assistance in a poor society generates cultural pressures that legitimize reduced investment in human resources. As Hannah and Iverson (2004, p. 334) state, in impoverished countries "many employers, if given the freedom to pay lower wages, will choose to do so".

System justification theory (Jost et al., 2003) explains how employees perceive lower investments in them by companies as appropriate (Bapuji, 2015). In order to minimize cognitive dissonance, employees justify and support the idea that the existing social system is fair, natural and inevitable, even at the expense of their own personal interests. Those who suffer most from a given state of affairs (i.e., people living in poverty) are, paradoxically, least likely to question or reject the status quo (Jost et al., 2003). Thus, the higher the level of poverty in society, the greater the cognitive legitimacy to accept the current labor market, despite its falling salaries, lower investment in training, and temporary contracting. For example, in Spain before the increase in poverty generated by the economic crisis, a salary of 1,000 euros per month was considered unacceptable and was morally rejected by employees (who were negatively described as "mileuristas"); currently, however, a salary of 1,000 euros 
is increasingly regarded as acceptable and is valued positively by employees. We therefore posit the following hypothesis:

H2. Poverty in a society (region) will negatively affect the HR investment of organizations within that region.

\section{METHODOLOGY}

\section{Sources of information and measures}

All the data we used in this study were taken from secondary data sources and produced by public institutions. The empirical research was carried out in Spain, a country with a high level of poverty that has grown in recent years and with great disparity in poverty rates among its regions (see Figure 1), known as autonomous communities (Llano-Ortiz, 2016; Węziak-Białowolska, 2015). Spain is a quasi-federal country with extensively decentralized basic public services (health, education and social protection) in its autonomous communities, which correspond to NUTS2 level regions in Europe (Eurostat, 2015). ${ }^{3}$ Following the Eurostat guidelines, the INE calculates annually the AROPE index for these Spanish regions. We used this public data for a six-year period (2006-2011), essentially because it includes years of growth (pre-2008) and economic crisis (post-2008), which has led to an increase of 3.7 percentage points in the AROPE index in Spain, from 24\% in 2006 to

\footnotetext{
${ }^{3}$ The NUTS classification (Nomenclature of territorial units for statistics) is a hierarchical system used to classify EU territories in three levels: NUTS1 (major socio-economic regions), NUTS2 (basic regions), and NUTS3 (small regions). The INE does not calculate the AROPE index at NUTS3 level. Eurostat identifies the cities of Ceuta and Melilla as NUTS2, extending the Spanish regions to 19, although these Spanish cities are not incorporated in our study because they are not included in the ESEE data.
} 
$27.7 \%$ in 2011 . AROPE scores were standardized to facilitate data analysis through structural equation modeling.

The Survey on Business Strategies (Encuesta sobre Estrategias Empresariales, ESEE) published annually by the SEPI Foundation (a public research institution supported by the Spanish government) was used to measure the organizational variables. The ESEE is a highquality database representative of the Spanish context, and is used in a wide range of empirical economic research carried out by both the internal services of the Ministry of Industry and a growing number of researchers who request data from the SEPI Foundation (SEPI Foundation, 2018). The ESEE reference population is Spanish manufacturing firms with ten or more employees, excluding industrial activities related to oil refining and treatment of fuels. The SEPI Foundation is responsible for the survey's design and administration. Firms are selected on the basis of a combination of exhaustiveness and random sampling criteria. Every year the survey is posted to a designated contact person in the firm who, subject to prior agreement with the SEPI Foundation, will respond to the survey questions. Most of the information requested is available in factual reports that are readily available to respondents. All the data included in the ESEE are subjected to reliability controls (SEPI Foundation, 2018).

We removed irregular cases that might skew the data from the original ESEE sample for the period 2006-2011 (2,713 firms). These cases included, first, firms affected by takeovers, divisions or mergers (327 firms), all of which prevent data being compared over time. Then we eliminated firms with industrial premises located in more than one region (153 firms), and those that moved from one region to another during the period studied (six firms). Finally, cases with outlier data for any of the organizational variables were excluded (35 firms). The final sample for analysis contained 2,192 firms, of which 877 firms presented complete data, the rest having some missing information. The average organizational size of 
the final sample during the six-year period was 125.33 employees. We describe in the Annex the distribution of firms by regions (Table I) and by industrial sector (Table II), using the Standard Industrial Classification system (SIC) and the Spanish National Classification of Business Activity (Clasificación Nacional de Actividades Económicas, CNAE).

Following Roca-Puig et al. (2012,2018), who also used the ESEE, we calculated the HR investment variable as the arithmetic mean of the standardized values of the employees' average salary, investment in training, and job security. The average salary was calculated as the ratio of labor costs to total number of employees. Investment in training was estimated as the ratio of training expenditure to total number of employees in the firm. Finally, job security was calculated as the percentage of all the firm's employees with a permanent contract. Similarly to Roca-Puig et al. (2018), labor productivity was measured with the ratio of value added to the number of employees in the firm, and a logarithmic transformation of this ratio was performed. The value added evaluated employees' labor efficiency by considering income in relation to operating costs.

Previous studies (e.g., Huselid, 1995) have identified organizational size, the firm's capital intensity, and its innovation strategy as organizational variables that can affect both HR investment and labor productivity. We therefore applied these three characteristics as control variables. Organizational size was measured as the logarithm of the total number of employees in the firm. Capital intensity was calculated as the logarithm of the ratio of net fixed assets to total number of employees. Level of business innovation was calculated as the ratio of the cost of investments in $R \& D$ activities to firm sales. As a control variable at regional level, we used the Regional Competitiveness Index (RCI), compiled by the European Commission, which is a composite index that measures the ability of a region to offer an attractive and sustainable environment for firms (Dijkstra et al., 2011). In our study we used the RCI 2010 index because the indicators it includes correspond to the initial years of our 
analysis period and this index was relatively stable over this six-year period in Spain. It can therefore be considered as a fixed factor that determines the level of development from which each Spanish region departs, and can affect both the capacity to invest in human resources and labor productivity of firms.

\section{Statistical procedure}

We combined previous data in such a way that the unit of analysis is the firm. Following Cole and Maxwell (2003) and Little (2013), we constructed a longitudinal structural equation model in which poverty acts simultaneously as an antecedent of HR investment and as a moderator of the effect of HR investment on labor productivity (Figure 2). When the independent variable is also the moderator, it is presented as one illustrative example of a moderated meditation model by Preacher et al. (2007; model A). In our dynamic panel data model, poverty and HR investment are mean-centered variables and we calculate the product term between the two (i.e., Poverty X HR investment) to introduce the moderator effect. The model includes both the autoregressive effects (relationships between the same variable over time) and the cross-lagged effects (relationships between different variables over time). In the specification of the model, we assume a time lag of 1 year for the crosslagged effects. The model in Figure 2 is restricted to be one way, the parameters of crosslagged effects between two variables in the different six times points $(t)$ are the same magnitude, and stationarity holds in the model (i.e., the unstandardized parameter estimates have the same value for the entire study period). Researchers often assume stationarity because a more parsimonious model facilitates interpretation of the results and allows them to make strong inferences (Cole and Maxwell, 2003). This restriction and the introduction of the autoregressive effects are also applied to the three organizational control variables. The regional control variable (i.e., RCI 2010) impacts on HR investment and labor productivity in the first time point of the period examined, that is, in the year 2006. 
We must also recall that the final sample included 1,315 firms with missing data. Missing values in longitudinal studies are more often the norm than the exception (Shin et al., 2009). It is therefore unsurprising that the percentage of cases with complete data is not very high. In this context, the full-information maximum likelihood (FIML) approach offers a practical way to use every piece of information collected without biasing the estimations of the model parameters that traditional elimination procedures (i.e., list-wise deletion) would imply (Little, 2013). In addition, when missing values are accompanied by non-normality, the robust FIML method has the least bias and yields the best parameter estimates (Shin et al., 2009). Robust FIML is implemented in the EQS program (Bentler, 2006) and computes the scaled chi-square $(\chi 2)$ Yuan-Bentler statistic, the normed fit index (NFI), the comparative fit index (CFI), and the root mean square error of approximation (RMSEA) index to assess the goodness of fit of the model to the data. In the context of missing values and non-normality, Shin et al. (2009) suggest using RMSEA based on the robust FIML solution as a basis for decisions regarding overall model fit. Finally, we used aggregated analysis to consider the dependence among cases nested within the same group (firms nested within regions) and lead to consistent parameter estimates of a structural equation model even if there are variables operating at different levels of analysis (Bentler, 2006).

\section{Insert figure 2 about here}

\section{RESULTS}

The goodness-of-fit indexes for the model show satisfactory values $\left(\chi^{2}(544)=\right.$ 3,277.577, $p .<0.01 ; N F I=0.937 ; C F I=0.942 ;$ RMSEA $=0.048)$. The unstandardized parameter estimates are presented and the robust test statistic is used to evaluate their level of 
significance (see Table 1). The longitudinal moderated mediation model consists of four substantive relations (Poverty $_{t} \rightarrow$ Labor productivity $_{t+1}$; Poverty Po $_{t} \rightarrow$ HR investment $_{t+1}$; Poverty $X$ HR investment $_{t} \rightarrow$ Labor productivity $_{t+1} ;$ HR investment $_{t} \rightarrow$ Labor productivity $\left._{t+1}\right)$; we found that all these relations are statistically significant over time. Hypothesis 1 (moderator effect) is confirmed because the product term presents a negative value $(-0.022)$ and, therefore, as levels of poverty in society increase, the positive effect of HR investment on labor productivity diminishes. Hypothesis 2 (antecedent effect) is also verified by the results, confirming that poverty in the society in which the organization is located has a negative effect on its HR investment (-0.055). In summary, we can verify that poverty in society reduces the propensity of firms to invest in human resources and, at the same time, reduces the profit of this business investment.

Insert table 1 about here

\section{CONCLUSION}

Organizations do not operate in isolated bubbles, oblivious to what happens in society and, therefore, the socioeconomic context in which they are located affects them. One of the challenges in the strategic HRM literature is to incorporate the societal context in which HR practices are embedded to understand their implementation and its effectiveness (Vincent et al., 2018). Heeding this call, we addressed the question of how poverty in society influences the willingness of firms to invest in employees and also moderates the impact of this investment on firm performance. In recent years, the level of poverty in society has risen in many developed countries, driving renewed research interest in this phenomenon across a range of scientific disciplines. Poverty remains one of the most persistent problems facing 
society (Haushofer and Fehr, 2014). The contextual social exchange theory provides a comprehensive framework with which to link society and organization. Cultural values related to social exchange in particular nations or regions (e.g., social trust) influences $a$ ) the size of inducement provided by employers, and $b$ ) the degree of loyalty that employees will show to employers and, consequently, the effectiveness of HR investment (Hannah and Iverson, 2004). The hypotheses we propose focus on this perspective. Poverty in society, characterized by social distrust, is a detrimental antecedent of HR investment and, at the same time, a harmful moderator of the inducement-contribution relationship because it interacts with HR investment, reducing its positive effect on labor productivity. Likewise, a good standard of living in a society will affect the employment relationship positively. Our findings corroborate these propositions and support the view that poverty needs to be taken into account in strategic HRM, showing, as Johns (2017) states, the importance of introducing contextual factors as variables that have an impact on organizational variables and can moderate them.

\section{Theoretical and practical implications}

Our research supports the claim by Coyle-Shapiro et al. (2004) that the employment relationship should not be analyzed exclusively in terms of reciprocity (exchange between HR investment and labor productivity) since it can be affected by the moral considerations prevailing in the community in which the company is located. We show that the social exchange relationship between an employer and its employees is dependent on the social trust embedded in the society. Social or generalized trust as a moral value is important because it answers questions that reciprocity between specific partners (i.e., strategic trust) in isolation from their environmental context cannot (Uslaner, 2002). In particular, it allows us to explain why and how the employee-organization relationship is weakened in an impoverished developed society. The social climate of non-collaboration in a poor society spreads to 
organizations, where it is reflected in the double negative impact of poverty on the employment relationship. We can borrow terms from Uslaner (2002) to say that social trust influences strategic trust.

On the other hand, the interaction between poverty and HR investment allows us to enter into the debate about how the resources available in society moderate the effect of the resources provided to employees within the organizational sphere (e.g., HR investment) on workforce performance. In this regard, Las Heras et al. (2015) identify two opposite positions: the complementary position (the fewer resources in society, the lower the impact of organizational resources), and the substitution position (the fewer resources in society, the greater the impact of organizational resources). Supporting the substitution vision, authors such as Diehl et al. (2018) and Las Heras et al. (2015) argue that in poor societies the absence of a basic societal safety net makes individuals heavily dependent on their jobs, and working conditions are particularly important and valued by employees. In such contexts, HR investment is especially useful to employees, who will respond with greater commitment to the organization and efficiency at work. Diehl et al. (2018) find empirical support for this hypothesis; however, Las Heras et al. (2015) empirically confirm the opposite view and provide support for the complementary vision. According to Las Heras et al. (2015) and Bosch et al. (2018), who embrace the contextual social exchange perspective, context has a normative function that legitimizes what people perceive as acceptable behaviors, and in poor environments characterized by non-cooperative behaviors, employees are less likely to act in a reciprocal way with the organization. Our findings concur with this complementary viewpoint.

The study of poverty in society links the strategic HRM literature with that of regional economics (e.g., Copus et al., 2015), which understands the location of a firm to be a basic competitive factor. We found support for this statement in that employees responded 
positively to reciprocation for past HR investment when they are embedded in a welfare society but indifferently when they are integrated in a disfavored society. In other words, the same amount of HR investment will produce better labor productivity when a company is located in a region with a higher standard of living. Therefore, the poverty of a region has a significant impact on organizations' competitiveness and emerges as an important societal factor for managers to consider when deciding where to locate a manufacturing plant. Bringing poverty in society into the equation also entails considering public institutionsparticularly regional governments - as fundamental actors, especially when social service expenditure is primarily managed at this regional level, as is the case of Spain. Any variation in the provision of these public services will have an impact on the level of poverty of the region. Finally, our study lends support to the idea that the degree to which poverty evolves and varies across a country's regions is highly relevant to the political decisions of European institutions to improve the competitiveness of the European economy (European Commission, 2010). We found a complementary interaction between society and organization, namely, the greater the society's welfare, the greater the business competitiveness, which leads to inclusive growth, a basic objective of the Europe 2020 strategy.

\section{Limitations and future research}

To study the society-organization link, poverty in society is an essential research area that has barely been explored. The model proposed in this paper should therefore be regarded as an initial step in examining how poverty in the organization's environment influences its HRM system and economic results. Issues such as poverty in society should be seen not only as a question of social justice, but also as a crucial question for organizations' development. From a methodological point of view, we used aggregated analysis to compute consistent parameter estimates with clustered data; however, this method cannot separate effects operating at societal and organizational levels (Bentler, 2006). To do this effectively requires 
a disaggregated analysis (i.e., multilevel models), which is not advisable when the sample size at the group level is only 17 (i.e., Spanish regions), and for which a minimum of 30 groups is required (Maas and Hox, 2005). Future research could therefore usefully increase the number of regions beyond this minimum, either by replicating this study in another country with more regions (e.g., USA), or by expanding the scope of analysis to incorporate other European regions, which would also allow for international comparisons. Moreover, we use a "panel model for longitudinal data" focus to ask and answer very important questions about change at the firm level (between-firm) related to variances and correlations among a set of variables (Little, 2013). Future research could use other types of longitudinal designs, such as "growth curve models" focused on intraindividual (within-firm) change that address questions regarding the rate and the shape of change that characterizes a particular sample of firms.

\section{Acknowledgments}

We are grateful to the anonymous reviewers and associate editor (Dr. Thomas Birtch) for their thoughtful suggestions, which have helped improve this paper substantially.

\section{REFERENCES}

Allen, M.R., Ericksen, J., and Collins, C.J. (2013). Human resource management, employee exchange relationships, and performance in small businesses. Human Resource Management, 52(2), 153-173.

Anand, S. and Sen, A. (1997). Concepts or Human Development and Poverty: A Multidimensional Perspective. United Nations Development Programme (UNDP), Human development papers, 1-20.

Atkinson, A. (1998). Poverty in Europe. Oxford: Blackwell Publishers. 
Bapuji, H. (2015). Individuals, interactions and institutions: How economic inequality affects organizations. Human Relations, 68, 1059-1083.

Batt, R. (2002). Managing customer services: Human resource practices, quit rates, and sales growth. Academy of Management Journal, 45, 587-597.

Bentler, P.M. (2006). EQS 6 Structural Equation Program Manual. Encino, CA: Multivariate software, Inc.

Bosch, M.J., Las Heras, M., Russo, M., Rofcanin, Y., and Grau, M.G. (2018). How context matters: The relationship between family supportive supervisor behaviours and motivation to work moderated by gender inequality. Journal of Business Research, 82, 46-55.

Bourguignon, F. (2004). The poverty-growth-inequality triangle. Agence Française de Développement, Paris.

Čiutienè, R., Meilienè, E., Savanevičienė, A., and Vaitkevičius, S. (2015). Interdependence between human capital and the power of a shadow economy: Lithuanian case study. Technological and Economic Development of Economy, 21(3), 460-482.

Cole, D.A. and Maxwell, S.E. (2003). Testing mediational models with longitudinal data: Questions and tips in the use of structural equation modeling. Journal of Abnormal Psychology, 112, 558-577.

Copus, A., Melo, P. C., Kaup, S., Tagai, G. and Artelaris, P. (2015). Regional poverty mapping in Europe-Challenges, advances, benefits and limitations. Local Economy, 30, 742-764.

Coyle-Shapiro, J.A., and Shore, L.M. (2007). The employee-organization relationship: Where do we go from here?. Human Resource Management Review, 17(2), 166-179. 
Coyle-Shapiro, J., Shore, L.M., Taylor, S., and Tetrick, L.E. (2004). The Employment relationship: Examining psychological and contextual perspectives. Oxford University Press, Oxford.

Cropanzano, R., and Mitchell, M.S. (2005). Social exchange theory: An interdisciplinary review. Journal of Management, 31(6), 874-900.

Delhey, J., and Newton, K. (2005). Predicting cross-national levels of social trust: global pattern or Nordic exceptionalism?. European Sociological Review, 21(4), 311-327.

Diehl, M.R., Richter, A., and Sarnecki, A. (2018). Variations in employee performance in response to organizational justice: The sensitizing effect of socioeconomic conditions. Journal of Management, 44(6), 2375-2404.

Dijkstra, L., Annoni, P., and Kozovska, K. (2011). A new regional competitiveness index: Theory, methods and findings. European Union Regional Policy Working Papers, 2, 2011.

European Commission (2010). Europe 2020. A strategy for smart, sustainable and inclusive growth. Communication from de Commission. Brussels.

Eurostat (2015). Regions in the European Union. Nomenclature of territorial units for statistics NUTS, 2013/EU-28. European Union.

Eurostat (2018) Living conditions in Europe. Publications Office of the European Union, Luxembourg.

Gábos, A., Branyiczki, R. Lange, B. and Tóth. I. (2015). Employment and poverty dynamics in the EU countries before, during and after the crisis. ImPRovE (Poverty Reduction in Europe: Social Policy and Innovation) Working Paper No. 15/06. University of Antwerp.

Hannah, D., and Iverson, R. (2004). Employment relationships in context: Implications for policy and practice. In Coyle-Shapiro, J., Shore, L.M., Taylor, S., and Tetrick, L.E. 
The Employment relationship: Examining psychological and contextual perspectives. Oxford University Press, Oxford. 332-350.

Haushofer, J. (2013). Psychology of poverty: evidence from 43 countries. Massachusetts Institute of Technology Working Paper; available at http://web.mit.edu/joha/www/publications/Haushofer_Psychology_of_Poverty_2013.0 9.14.pdf).

Haushofer, J., and Fehr, E. (2014). On the psychology of poverty. Science, 344, 862-867.

Huselid, M.A. (1995). The impact of human resource management practices on turnover, productivity, and corporate financial performance. Academy of Management Journal, $38,635-672$.

Iceland, J. (2003). Why poverty remains high: The role of income growth, economic inequality, and changes in family structure, 1949-1999. Demography, 40(3), 499-519.

Jackson, S.E., Schuler, R.S. and Jiang, K. (2014). An aspirational framework for strategic human resource management. Academy of Management Annals, 8, 1-56.

Johns, G. (2017). Reflections on the 2016 decade award: incorporating context in organizational research. Academy of Management Review, 42, 577-595.

Jost, J.T., Pelham, B.W., Sheldon, O. and Ni Sullivan, B. (2003). Social inequality and the reduction of ideological dissonance on behalf of the system: Evidence of enhanced system justification among the disadvantaged. European Journal of Social Psychology, 33, 13-36.

Kaufman, B.E. (2012). Strategic human resource management research in the United States: A failing grade after 30 years?. Academy of Management Perspectives, 26, 12-36.

Kim, S. and Wright, P.M. (2011). Putting strategic human resource management in context: A contextualized model of high commitment work systems and its implications in China. Management and Organization Review, 7(1), 153-174. 
Kolk, A., Rivera-Santos, M. and Rufín, C. (2014). Reviewing a decade of research on the “base/bottom of the pyramid” (BOP) concept. Business \& Society, 53, 338-377.

Las Heras, M., Trefalt, S., and Escribano, P.I. (2015). How national context moderates the impact of family-supportive supervisory behavior on job performance and turnover intentions. Management Research: The Journal of the Iberoamerican Academy of Management, 13(1), 55-82.

Leana, C. R., Mittal, V. and Stiehl, E. (2012). Organizational behavior and the working poor. Organization Science, 23, 888-906.

Lee, J. and Miller, D. (1999). People matter: Commitment to employees, strategy and performance in Korean firms. Strategic Management Journal, 20, 579-593.

Llano-Ortiz, J.C. (2016). El estado de la pobreza. Seguimiento del indicador de riesgo de pobreza y exclusión social en España 2009-2015. European Antipoverty Network (EAPN), Madrid.

Lewis, A.C., Cardy, R.L., and Huang, L.S. (2018). Institutional theory and HRM: A new look. Hesource Management Review. https://doi.org/10.1016/j.hrmr.2018.07.006

Little, T.D. (2013). Longitudinal structural equation modeling. New York: Guilford Press.

Maas, C. J., and Hox, J.J. (2005). Sufficient sample sizes for multilevel modeling. Methodology, 1(3), 86-92.

March, J.G., and Simon, H.A. (1958). Organizations. New York: Wiley.

Piacentini, M. (2014). Measuring income inequality and poverty at the regional level in OECD countries. Statistics Working Papers, 2014/03, OECD Publishing.

Pitesa, M., Thau, S., and Pillutla, M. (2017). Workplace trust as a mechanism of employee (dis) advantage: The case of employee socioeconomic status. Research in Organizational Behavior, 37, 83-101. 
Popov, A. (2014). Credit constraints and investment in human capital: Training evidence from transition economies. Journal of Financial Intermediation, 23(1), 76-100.

Preacher, K.J., Rucker, D. D., and Hayes, A.F. (2007). Addressing moderated mediation hypotheses: Theory, methods, and prescriptions. Multivariate Behavioral Research, 42(1), 185-227.

Roca-Puig, V., Beltrán-Martín, I. and Segarra-Ciprés, M. (2012). Commitment to employees, labor intensity, and labor productivity in small firms. International Journal of Manpower, 33, 938-954.

Roca-Puig, V., Bou-Llusar, J. C., Beltrán-Martín, I., and García-Juan, B. (2018) The virtuous circle of human resource investments: A precrisis and postcrisis analysis. Human Resource Management Journal. https://doi.org/10.1111/1748-8583.12213

Roh, H., and Kim, E. (2016). The business case for gender diversity: Examining the role of human resource management investments. Human Resource Management, 55(3), 519534.

Rothstein, B., and Uslaner, E.M. (2005). All for all: Equality, corruption, and social trust. World Politics, 58(1), 41-72.

Saridakis, G., Lai, Y., and Cooper, C.L. (2017). Exploring the relationship between HRM and firm performance: A meta-analysis of longitudinal studies. Human Resource Management Review, 27(1), 87-96.

Schalk, R. (2004). Changes in the employment relationship across time. In Coyle-Shapiro, J., Shore, L. M., Taylor, S., and Tetrick, L. E. The Employment Relationship; Examining Psychological and Contextual Perspectives. Oxford University Press, Oxford. 284311

SEPI Foundation (2018, July 30). "Survey on business strategy (ESEE)". Retrieved from https://www.fundacionsepi.es/investigacion/esee/en/spresentacion.asp. 
Shaw, J.D., Dineen, B.R., Fang, R., and Vellella, R.F. (2009). Employee-organization exchange relationships, HRM practices, and quit rates of good and poor performers. Academy of Management Journal, 52(5), 1016-1033.

Shaw, J.D., Delery, J.E., Jenkins, G.D., and Gupta, N. (1998). An organization-level analysis of voluntary and involuntary turnover. Academy of Management Journal, 41(5), 511525.

Shin, T., Davison, M.L., and Long, J.D. (2009). Effects of missing data methods in structural equation modeling with nonnormal longitudinal data. Structural Equation Modeling, 16(1), 70-98.

Steijn, S., and Lancee, B. (2011). GINI DP 20: Does Income Inequality Negatively Affect General Trust? Examining three potential problems with the inequality-trust hypothesis. GINI Discussion Papers 20, AIAS, Amsterdam Institute for Advanced Labour Studies.

Subramony, M., Krause, N., Norton, J., and Burns, G.N. (2008). The relationship between human resource investments and organizational performance: a firm-level examination of equilibrium theory. Journal of Applied Psychology, 93(4), 778-788.

Suchman, M.C. (1995). Managing legitimacy: Strategic and institutional approaches. Academy of Management Review, 20(3), 571-610.

Sun, L. Y., Aryee, S., and Law, K. S. (2007). High-performance human resource practices, citizenship behavior, and organizational performance: A relational perspective. Academy of management Journal, 50(3), 558-577.

Tsui, A.S., Pearce, J.L., Porter, L.W., and Tripoli, A.M. (1997). Alternative approaches to the employee-organization relationship: Does investment in employees pay off? Academy of Management Journal, 40(5), 1089-1121. 
UNDP (United Nations Development Programme) (1997). Human Development Report 1997. New York: Oxford University Press.

Uslaner, E.M. (2002). The moral foundations of trust. Cambridge University Press, New York.

Vincent, S., Bamber, G. J., Delbridge, R., Doellgast, V., Grady, J., and Grugulis, I. (2018). Special issue call for papers: situating human resource management practices in their political and economic context. Human Resource Management Journal.

Wagle, U. (2008). Multidimensional poverty measurement: Concepts and applications. Springer, New York.

Wang, D., Tsui, A.S., Zhang, Y., and Ma, L. (2003). Employment relationships and firm performance: Evidence from an emerging economy. Journal of Organizational Behavior: 24(5), 511-535.

Warren, M.E. (2018). Trust and democracy. In Uslaner, E.M. (ed.) The Oxford handbook of social and political trust. Oxford University Press, New York. 75-94

Węziak-Białowolska, D (2015). Poverty in the regions of the European Union - Measurement with a composite indicator. Contemporary Economics, 9, 113-154.

You, J.S. (2018). Trust and corruption. In Uslaner, E.M. (ed.) The Oxford handbook of social and political trust. Oxford University Press, New York. 473-496 
Figure 1. Theoretical model

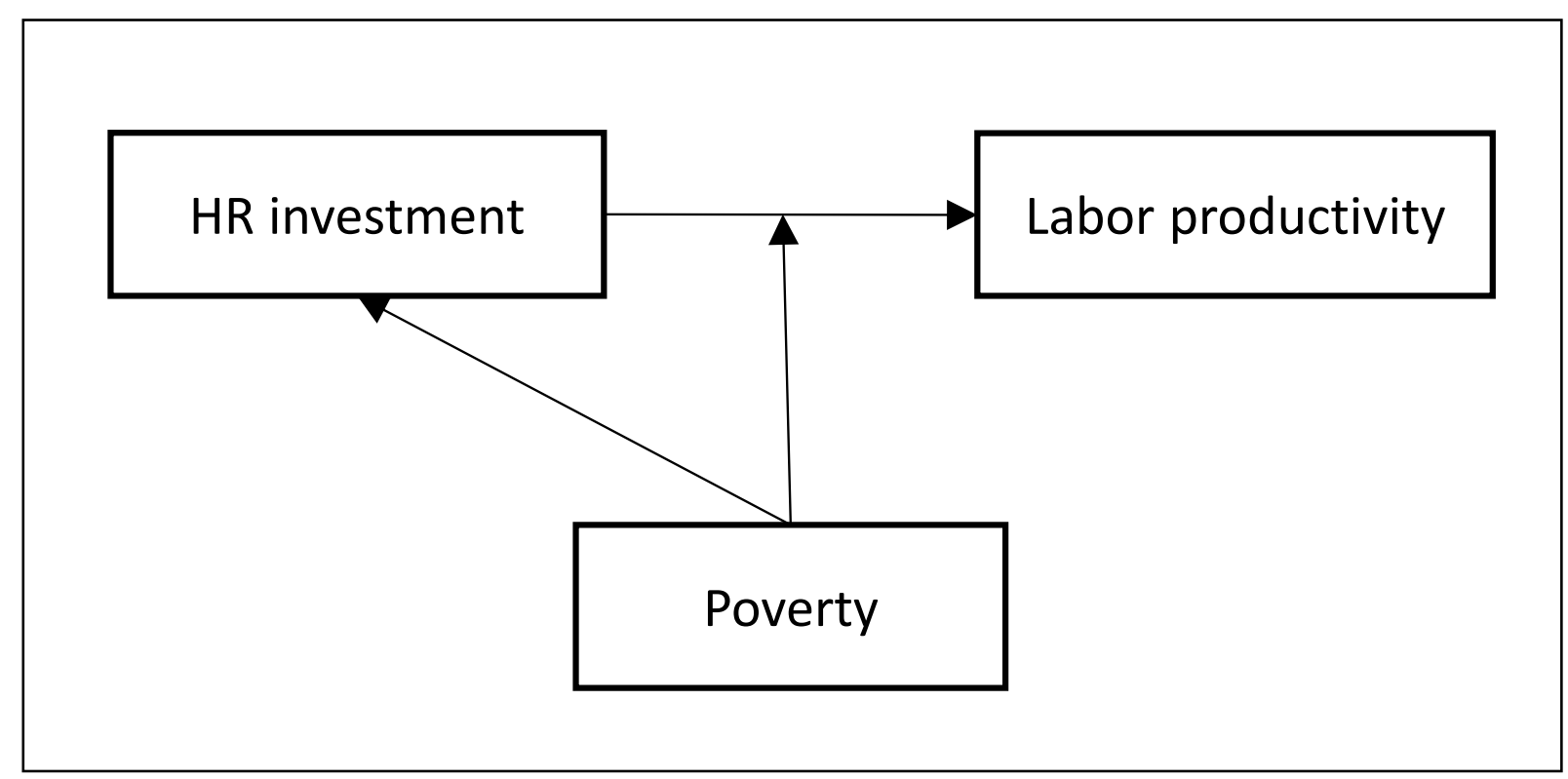


Figure 2. Longitudinal design for the period 2006-2011 $(t=6)$

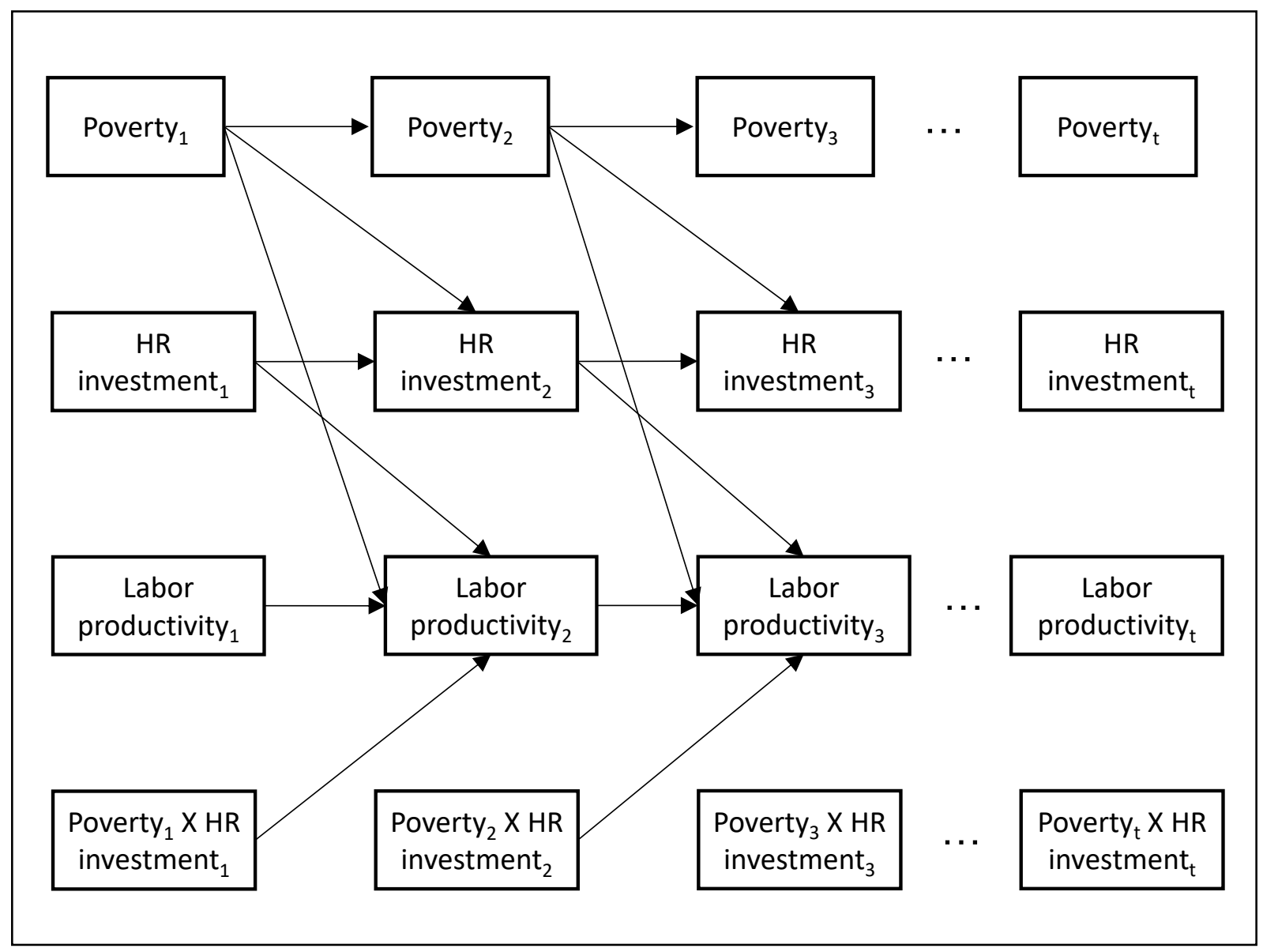

Note. Each moderator variable correlates with each of the other variables except where the directed path of a moderator variables on the outcome variable is specified (i.e., labor productivity at the next time of measurement); and all non-moderator variables correlate with each other within each time of measurement. See Little (2013) for a more detailed explanation. For the sake of simplicity, these covariances and the control variables relations are omitted in this graphical representation. 


\section{Relations}

Poverty $_{t} \rightarrow$ Labor productivity $_{t+1}$

Poverty $_{t} \rightarrow$ HR investment $_{t+1}$

HR investment $_{t} \rightarrow$ Labor productivity $_{t+1}$

Poverty ${ }_{t}$ X HR investment $t_{t} \rightarrow$ Labor productivity $_{t+1}$

Control variables

Organizational size $_{t} \rightarrow$ HR investment $_{t+1}$

Organizational size $_{t} \rightarrow$ Labor productivity $_{t+1}$

Capital intensity $_{t} \rightarrow$ HR investment $_{t+1}$

Capital intensity $_{t} \rightarrow$ Labor productivity $_{t+1}$

Innovation intensity $_{t} \rightarrow$ HR investment $_{t+1}$

Innovation intensity $_{t} \rightarrow$ Labor productivity $_{t+1}$

Regional competitiveness $\rightarrow$ HR investment ${ }_{l}$

Regional competitiveness $\rightarrow$ Labor productivity 1

Autoregressive

Poverty $_{t} \rightarrow$ Poverty $_{t+1}$

HR investment $_{t} \rightarrow$ HR investment $t_{t+1}$

Labor productivity $_{t} \rightarrow$ Labor productivity $_{t+1}$

Organizational size $_{t} \rightarrow$ Organizational size $_{t+1}$

Capital intensity $_{t} \rightarrow$ Capital intensity $_{t+1}$

Innovation intensity $_{t} \rightarrow$ Innovation intensity $_{t+1}$

Parameter estimates

$$
\begin{gathered}
-0.020^{* * *} * \\
-0.055^{* * *} * \\
0.044 * * * \\
-0.022 * * * \\
0.090 * * * \\
0.040 * * * \\
0.053 * * * \\
0.065 * * * \\
0.007 * * \\
0.000 \\
0.016 * * * \\
0.004 * * *
\end{gathered}
$$

$$
\begin{aligned}
& (0.904-0.966) * * * \\
& (0.721-0.784) * * * \\
& (0.501-0.769) * * * \\
& (0.997-1.011) * * * \\
& (0.923-0.982) * * * \\
& (0.710-1.002) * * *
\end{aligned}
$$

Note. The range of variation (minimum-maximum) of the autoregression coefficients during the period analyzed is shown in parenthesis. $* \mathrm{p}<0.10 ; * * \mathrm{p}<0.05 ; * * * \mathrm{p}<0.01 . \quad N=2,192$. 


\section{ANNEX}

Figure I. Evolution of poverty by Spanish regions

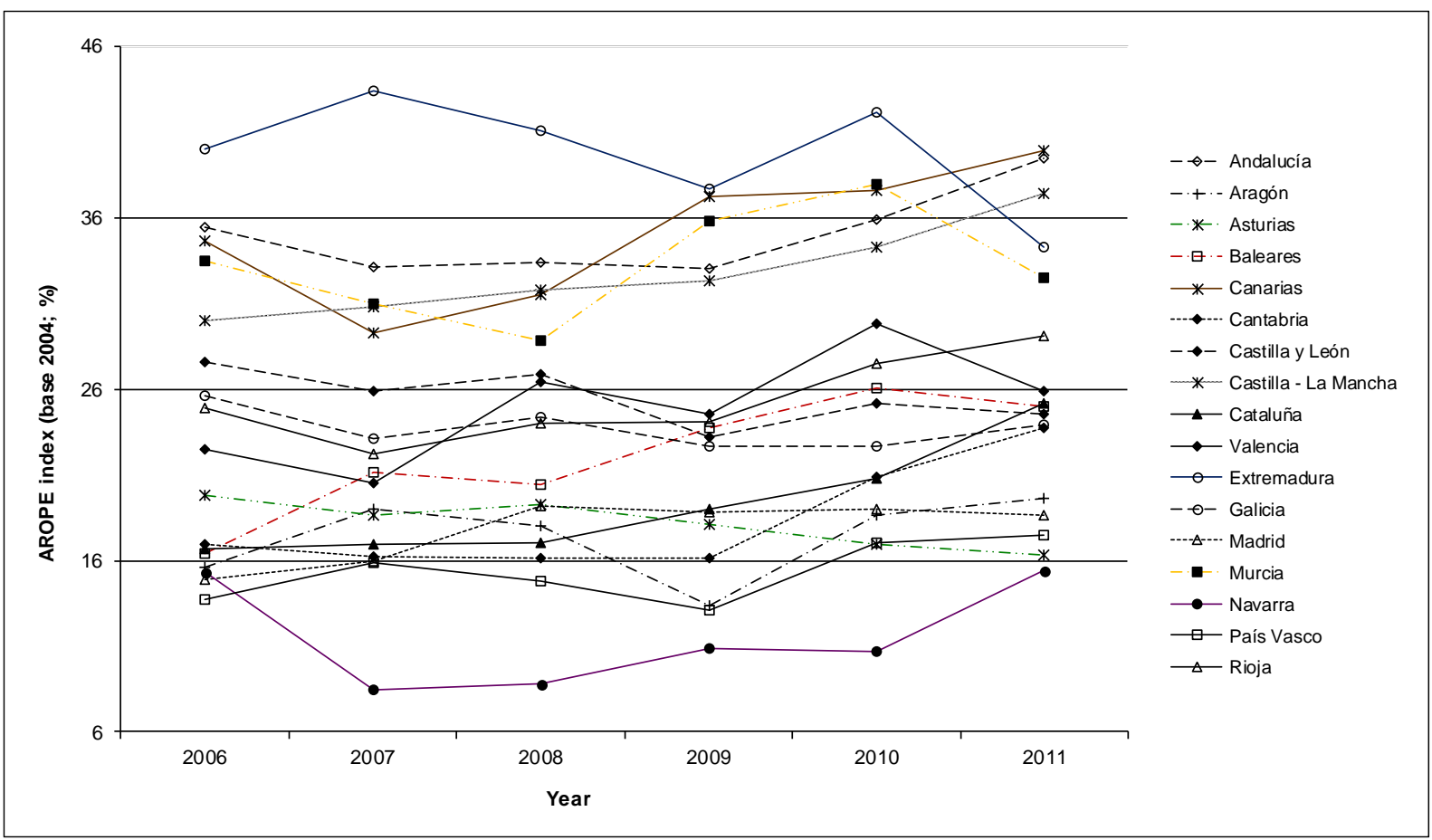

Source: INE

Table I. Distribution of firms by regions

\begin{tabular}{lcc}
\hline Region & Number & Percentage \\
\hline Andalucía & 225 & $10.2 \%$ \\
Aragón & 89 & $4.0 \%$ \\
Asturias & 56 & $2.5 \%$ \\
Baleares & 28 & $1.3 \%$ \\
Canarias & 34 & $1.5 \%$ \\
Cantabria & 27 & $1.2 \%$ \\
Castilla y León & 105 & $4.8 \%$ \\
Castilla-La Mancha & 123 & $5.6 \%$ \\
Cataluña & 424 & $19.2 \%$ \\
Valencia & 333 & $15.1 \%$ \\
Extremadura & 32 & $1.4 \%$ \\
Galicia & 144 & $6.5 \%$ \\
Madrid & 260 & $11.8 \%$ \\
Murcia & 62 & $2.8 \%$ \\
Navarra & 54 & $2.4 \%$ \\
País vasco & 167 & $7.6 \%$ \\
Rioja & 29 & $1.3 \%$ \\
Total & 2,192 & $100 \%$ \\
\hline
\end{tabular}


Table II. Distribution of firms by sectors of activity

\begin{tabular}{|c|c|c|c|}
\hline SIC & CNAE & Number & Percentage \\
\hline 20 and 21 & Food, drink and tobacco industry & 301 & $13.7 \%$ \\
\hline 22 and 23 & Textile and clothing industry & 179 & $8.2 \%$ \\
\hline 31 & Leather and footwear industry & 69 & $3.3 \%$ \\
\hline 24 and 25 & Timber and cork industry & 95 & $4.3 \%$ \\
\hline 26 and 27 & Paper industry & 187 & $8.5 \%$ \\
\hline 28 & Chemical industry & 120 & $5.5 \%$ \\
\hline 30 & Rubber transformation and plastic materials industry & 109 & $5.0 \%$ \\
\hline 32 & Other mineral, non-metallic product industries & 174 & $7.9 \%$ \\
\hline 33 and 34 & Primary metal industry and manufacturing of metal products & 372 & $17.2 \%$ \\
\hline 35 and 36 & Machinery and electrical equipment manufacturing industry & 141 & $6.4 \%$ \\
\hline 38 & Electrical, electronic and equipment industry & 128 & $5.8 \%$ \\
\hline 37 & Manufacturing of transportation equipment industry & 127 & $5.8 \%$ \\
\hline \multirow[t]{2}{*}{39} & Miscellaneous manufacturing industries & 182 & $8.3 \%$ \\
\hline & Total & 2,192 & $100 \%$ \\
\hline
\end{tabular}

